\title{
Genus Symphysodontella M. Fleisch. (Pterobryaceae: Bryophyta) - new to the moss flora of the Eastern Ghats
}

\author{
A. E. D. Daniels, M. M. Preetha, V. Asha and P. M. Biju \\ Bryology Laboratory, Department of Botany \& Research Centre, Scott Christian College (Autonomous), Nagercoil 629003, India
}

\section{Article history}

Received: 22 November 2017 Accepted: 23 December 2017

Published: 02 January 2018

(C) Daniels et al. (2018)

Editor

Afroz Alam

Publisher

Horizon e-Publishing Group

Correspondence

A. E. D. Daniels

\dulipdaniels@yahoo.co.uk

\begin{abstract}
Surveys carried out in the Kolli Hills of Eastern Ghats resulted in the discovery of 2 species of Symphysodontella M. Fleisch. namely S. cylindracea (Mont.) M. Fleisch. and $S$. involuta (Thwaites \& Mitt.) M. Fleisch. of which the former is new to the moss flora of India whereas the latter is new to the moss flora of Eastern Ghats. Detailed descriptions with figures substantiated by photo plates and a key to distinguish the two species are provided. Incidentally, genus Symphysodontella is new to the moss flora of Eastern Ghats.
\end{abstract}

\section{Keywords}

Bryophyta; Eastern Ghats; Pterobryaceae; Symphysodontella; S. cylindracea; S. involuta

\section{Citation}

Daniels A E D, Preetha M M, Asha V and Biju P M. Genus Symphysodontella M. Fleisch. (Pterobryaceae: Bryophyta) - new to the moss flora of the Eastern Ghats. Plant Science Today 2018; 5(1):19-23. doi: https://dx.doi.org/10.14719/pst.2018.5.1.364

\section{Introduction}

Symphysodontella M. Fleisch., with 9 species in the world, is predominantly an insular genus Magill [1]. The species are mostly distributed in South and Southeast Asian Islands, and South Pacific Islands. In India, only 2 species namely Symphysodontella involuta and $S$. tortifolia Dixon are reportedly known so far. Of these, S. tortifolia is endemic to India and S. involuta is endemic to Peninsular India and Sri Lanka.

Gangulee [2], reported 4 species namely $S$. borii Dixon, S. tortifolia, S. subulata Broth. and $S$. pilifolia Dixon. Lal [3]] and Dandotiya et al. [4], included one more species $S$. involuta in their checklists raising the number to 5. However, Magill [1] proposed new combinations to $S$. borii and $S$. pilifolia as Myurium borii (Dixon) Magill and
Pterobryopsis pilifolia (Dixon) Magill respectively thereby reducing the number of species to 3 . Moreover, according to Magill [1], the material of Symphysodontella subulata reported by Dixon [5] based on Bor's collection (Bor 93b) and included by Gangulee [2] is a depauperate form of $S$. tortifolia and thus $S$. subulata is endemic to the Philippines. Recently, Manju and Rajesh [6] described Symphysodontella madhusoodananii as new to plant science from the Western Ghats which is an addition to the already known species in India and the World as well.

Surveys carried out in the Kolli Hills of Eastern Ghats resulted in the discovery of 2 species of Symphysodontella namely $S$. cylindracea and $S$. involuta of which the former is new to the moss flora of India whereas the latter is an addition to the moss flora of Eastern Ghats. Thus, currently there are 4 


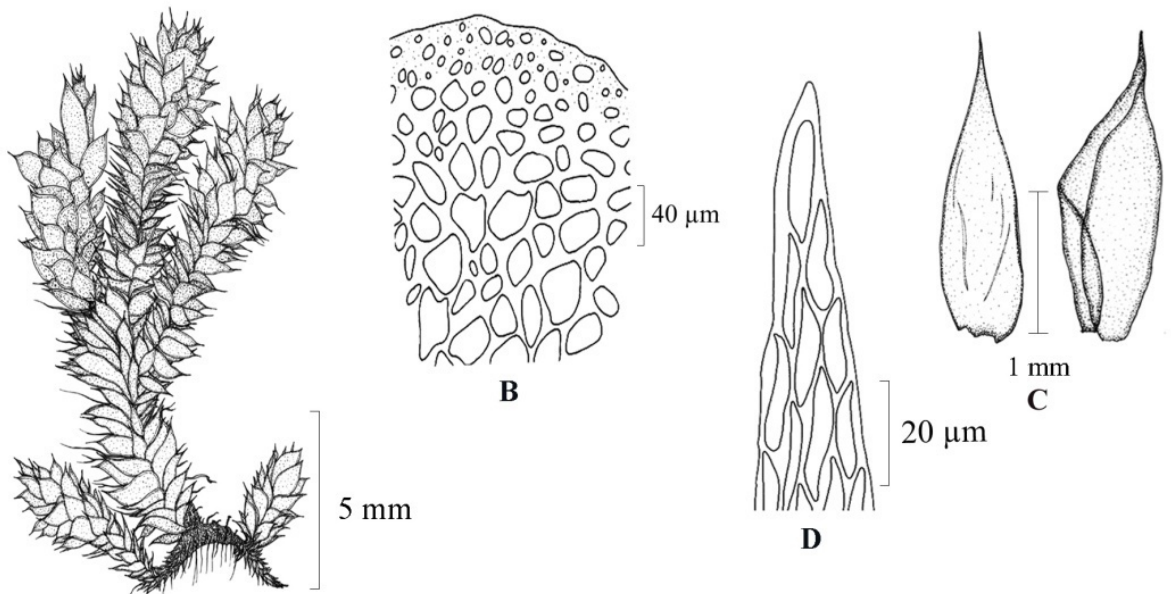

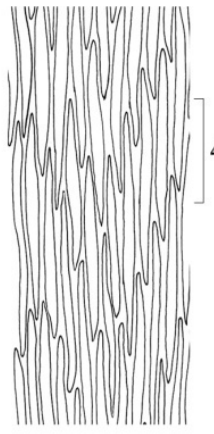

$\mathbf{E}$

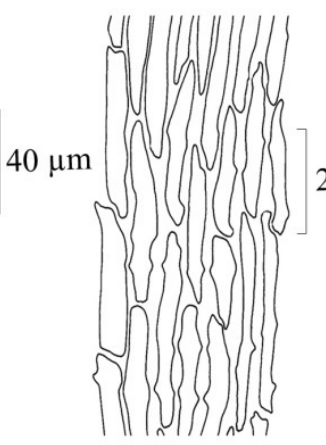

$\mathbf{F}$

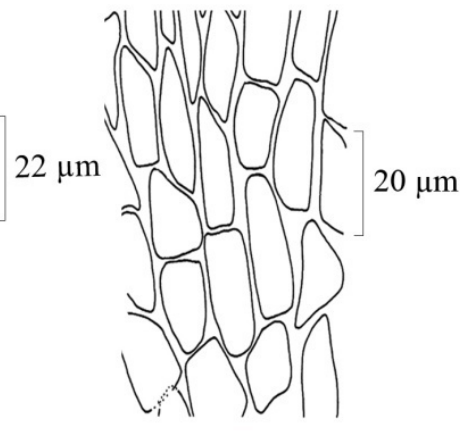

G

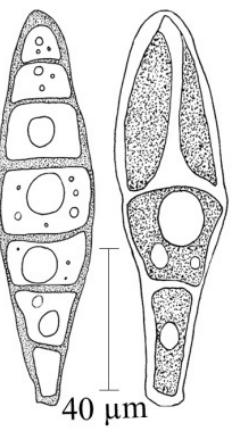

H

Fig. 1. Symphysodontella cylindracea (Mont.) M. Fleisch.

A. Plant B. Portion of cross section of stem C. Leaves D. Leaf apical cells

D. Leaf median cells F. Leaf basal cells G. Alar cells H. Gemmae (P. M. Biju 2074)

species in India namely $S$. cylindracea, $S$. involuta, S. tortifolia and S. madhusoodananii C.N. Manju \& K.P. Rajesh. Incidentally, genus Symphysodontella M. Fleisch., so far known to be distributed in the Northeast, Eastern Himalaya and the Western Ghats in India, is added here to the moss flora of the Eastern Ghats. Detailed descriptions with figures substantiated by photo plates and a key to distinguish the two species are provided. The specimens are deposited at SCCN.

\section{Key to the species}

1a. Costa single, 2/3 as long as leaves; alar region tinted to red-brown

2. S. involuta

b. Costa double, short, faint; alar region yellowbrown 1. S. cylindracea

1. Symphysodontella cylindracea (Mont.) M. Fleisch., Musc. Buitenzorg 3: 692. 1908. Neckera cylindracea Mont., Ann. Sci. Nat. Bot. 3, 10: 109. 1848. - Type: Tahiti, Nadeaud s.n. 1896 (NY). (Figs. 1 \& 2)

Plants pale green, glossy. Stems creeping, 2 $4 \mathrm{~cm}$ long, wiry, irregularly pinnately branched, dark brown, ca $0.24 \times 0.20 \mathrm{~mm}$ in cross section, ovate, without a central strand; cortex 3- or 4layered; cells $4-12 \times 3-8 \mathrm{~mm}$, thick-walled; medullary ones $12-24 \times 8-20 \mathrm{~mm}$, thin-walled; branches ascending or pendant, $1-3 \mathrm{~cm}$ long. Leaves dense, erectopatent, ovate-oblong to ovatelanceolate, cucullate, entire, slightly convolute or not, acute to acuminate; stem leaves $2-2.8 \times 1-1.1$ $\mathrm{mm}$; branch leaves $1.9-2.8 \times 0.7-0.9 \mathrm{~mm}$; cells narrow, elongate, incrassate, with distinctly porose walls below and faintly porose above; apical cells 36 - $48 \times 8$ - $12 \mu \mathrm{m}$; median ones 40 - $68 \times 4-8 \mu \mathrm{m}$; those at base $30-68 \times 8-16 \mu \mathrm{m}$; alar cells $24-40 \times$ 16 - $24 \mu \mathrm{m}$, oblong, yellow-brown; costa short, double, sometimes longer on one side or bifurcate at base. Gemmae at leaf base, clustered, fusiform, stalked, 3 - 7-celled, $0.09-0.19 \times 0.03-0.04$. Sporophyte not seen.

Habitat: Rupicolous in degraded evergreen forests, ca $1240 \mathrm{~m}$.

Distr.: Indonesia, Malaysia, the Philippines, New Caledonia, Papua New Guinea, New Hebrides, Fiji, Phoenix Islands, Cook Islands, Samoan Islands, Society Islands, Tahiti and India: Eastern Ghats of Tamil Nadu (Namakkal).

Specimens examined: Eastern Ghats: Tamil Nadu, Namakkal Dist., Kolli Hills, Sholakkadu, Kuzhivalavu Shola, ca 1240 m, 28.12.2016, P.M. Biju 2074. 


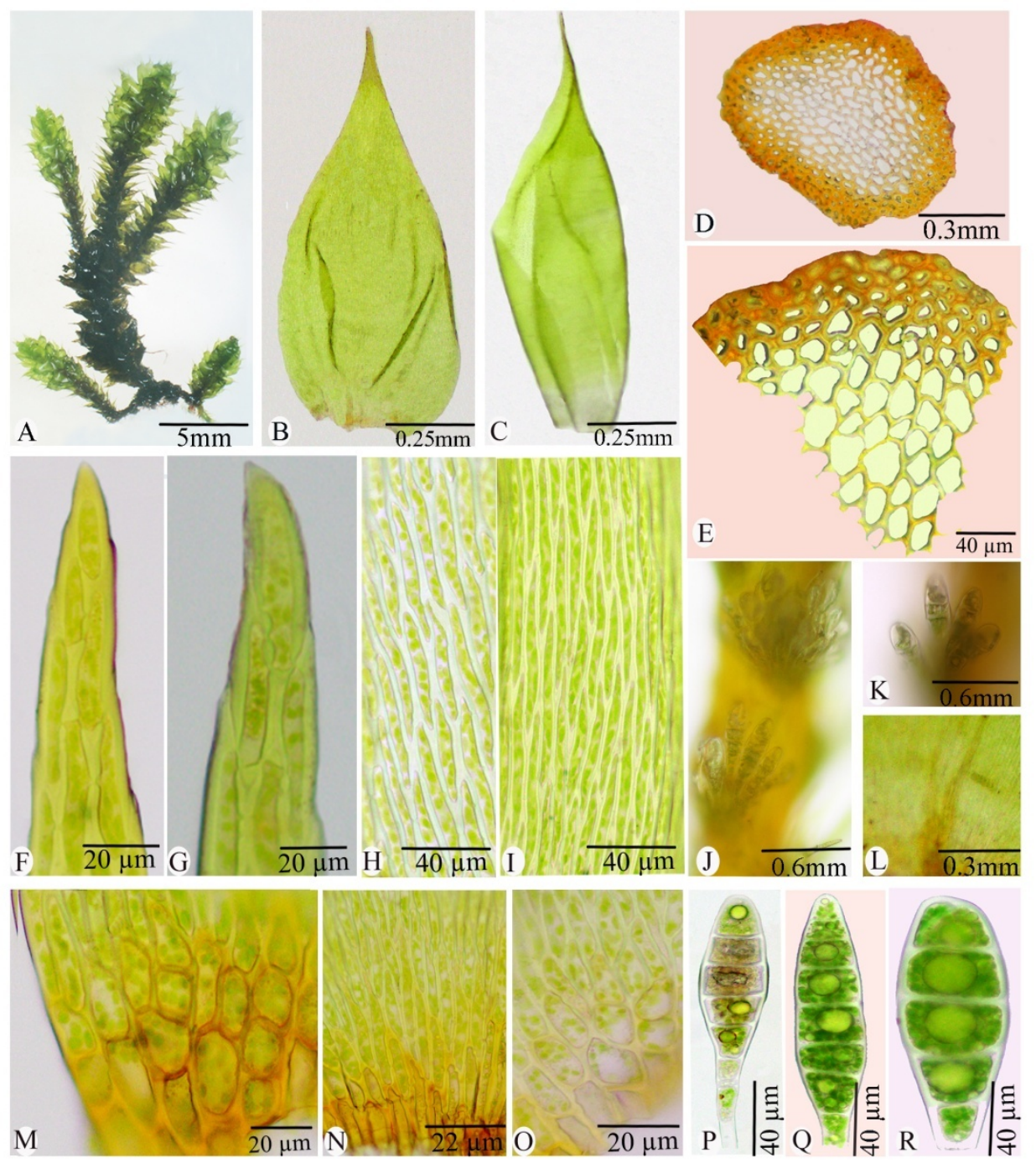

Fig. 2. Symphysodontella cylindracea (Mont.) M. Fleisch.

A. Plant B\&C. Leaves Stem leaf D. Cross section of stem E. A portion enlarged

F\&G. Leaf apical cells $\mathbf{H} \& \mathbf{I}$. Leaf median cells $\mathbf{J} \& \mathbf{K}$. Cluster of gemmae at leafbase

L. Costa M. Alar cells N\&O. Leaf basal cells P-R. Gemmae (P. M. Biju 2074)

2. Symphysodontella involuta (Thwaites \& Mitt.) M. Fleisch., Musc. Buitenzorg 4: 1674. 1923. Pterobryum involutum Thwaites \& Mitt., J. Linn. Soc., Bot. 13: 315. 1873. - Type: Ceylon, Central Province, 4000 - 6000 ft., Thwaites s.n. (BM). (Figs. $3 \& 4)$

Plants pale green to pale brownish-green, glossy. Stems creeping, 2 - $4 \mathrm{~cm}$ long, wiry, irregularly pinnately branched, dark brown, 0.11 $0.24 \times 0.09-0.20 \mathrm{~mm}$ in cross section, ovate, without a central strand; cortex 2- or 3-layered; cells 4 - $8 \times 3$ - $6 \mathrm{~mm}$, thick-walled; medullary ones $8-24 \times 4-14 \mathrm{~mm}$, thin-walled; branches ascending or pendant, $2-3 \mathrm{~cm}$ long. Leaves dense, erectopatent, oblong to ovate-lanceolate, cucullate, plicate, cordate to rounded, entire, convolute or not, acuminate to long-acuminate; stem leaves 3 $5.5 \times 1.6-2 \mathrm{~mm}$; branch leaves $3-5.2 \times 1.5-1.9$ $\mathrm{mm}$; cells narrow, elongate, incrassate, with distinctly porose walls below and faintly porose above; apical cells 16 - $40 \times 8$ - $12 \mu \mathrm{m}$; median ones
$36-68 \times 8-12 \mu \mathrm{m}$; those at base $20-40 \times 10-14$ $\mu \mathrm{m}$; alar cells $12-24 \times 8-20 \mu \mathrm{m}$, indistinct, rectangular, tinted to red-brown; costa single, almost $2 / 3$ as long as leaves, sometimes bifurcate at base. Sporophyte not seen.

Habitat: Rupicolous in degraded evergreen forests, ca $1300 \mathrm{~m}$.

Distr.: Sri Lanka and India: Western Ghats of Kerala, Tamil Nadu (Kanyakumari, Madurai and Tirunelveli) and Eastern Ghats of Tamil Nadu (Namakkal).

Specimens examined: Eastern Ghats: Tamil Nadu, Namakkal Dist., Kolli Hills, Sholakkadu, Kuzhivalavu Shola, ca 1300 m, 28.12.2016, P.M. Biju 2080, 2094.

\section{Discussion}

The Eastern Ghats, one of the bryogeopgraphical zones of the country, is underexplored as far as 


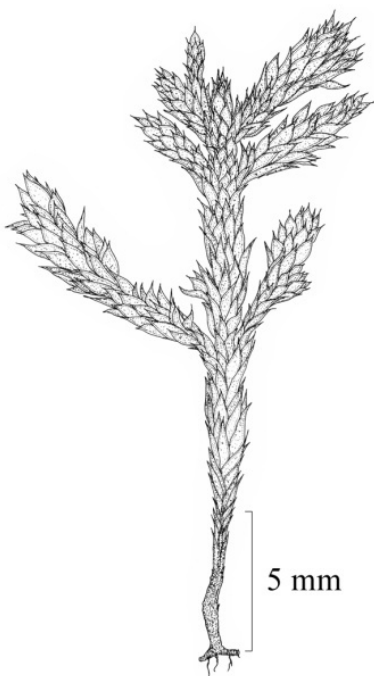

A
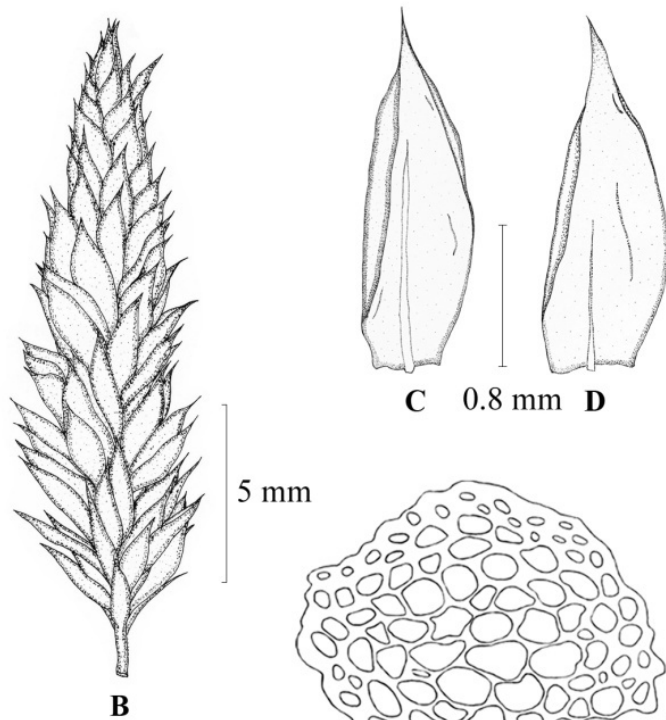

C $\quad 0.8 \mathrm{~mm} \mathrm{D}$

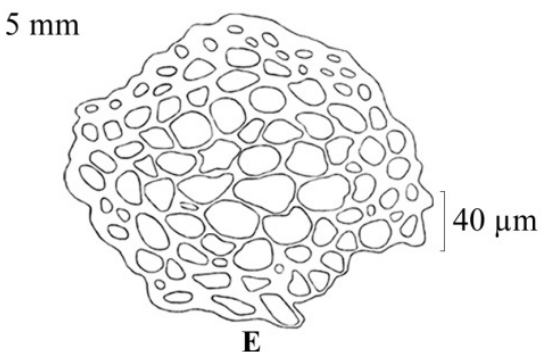

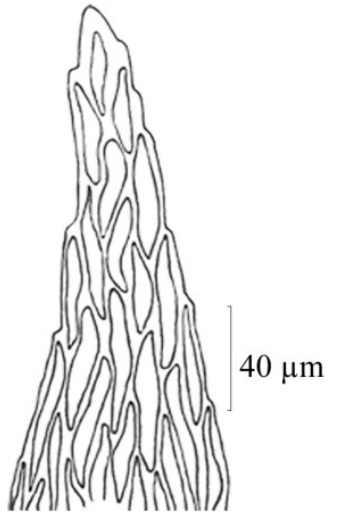

F

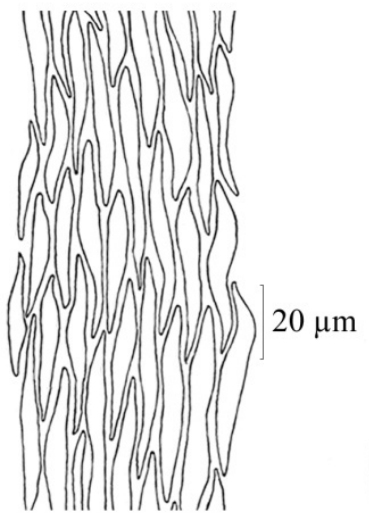

G

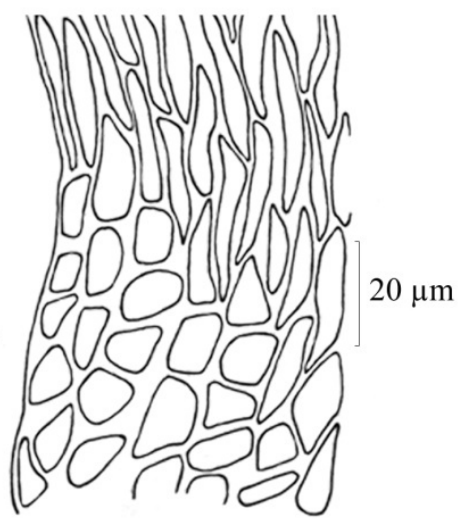

H

Fig. 3. Symphysodontella involuta (Thwaites \& Mitt.) M. Fleisch.

A. Plant B. Portion of plant C. Stem leaf D. Branch leaf E. Cross section of stem

F. Leaf apical cells G. Leaf median cells H. Leaf basal cells (P. M. Biju 2080)

bryophytes are concerned. The new reports made by Kumar and Krishnamurthy [7], Sathish et al. [8], Biju and Daniels [9,10,11] and Palani et al. [12] testify to this. The discovery of Symphysodontella cylindracea and Symphysodontella involuta reiterates the need for more rigorous studies on the bryoflora of the Eastern Ghats. The occurrence of $S$. involuta in the Eastern Ghats highlights the affinity of Eastern Ghats to that of the Western Ghats-Sri Lanka biogeographic unit.

\section{Authors' contribution}

AEDD - identification and writing and formatting of the MS; PMB - collection, dissection and help in identification; MMP and VA - dissection, figures, photographic plates and help in identification.

\section{Acknowledgements}

We thank the Tamil Nadu State Forest Department for permission to explore the study area and help in the field. AEDD thanks the Ministry of Environment, Forests \& Climate Change, Govt. of India, New Delhi, for financial assistance, and the Principal, Scott Christian College, for facilities.

\section{Conflict of interest}

The authors declare that they have no competing interests.

\section{References}

1. Magill RE. A monograph of the genus Symphysodontella (Pterobryaceae, Musci). J. Hattori Bot. Lab. 1980; 48: 33-70.

2. Gangulee HC. Mosses of Eastern India and adjacent regions. Calcutta. 1976; Vol. 2(5): 1135-1462.

3. Lal J. A checklist of Indian mosses. Dehra Dun: Bishen Singh Mahendra Pal Singh; 2005. P. 1-164.

4. Dandotiya D, Govindapyari H, Suman S, Uniyal PL. Checklist of the bryophytes of India. Arch. Bryol. 2011; 88: 1-126. 


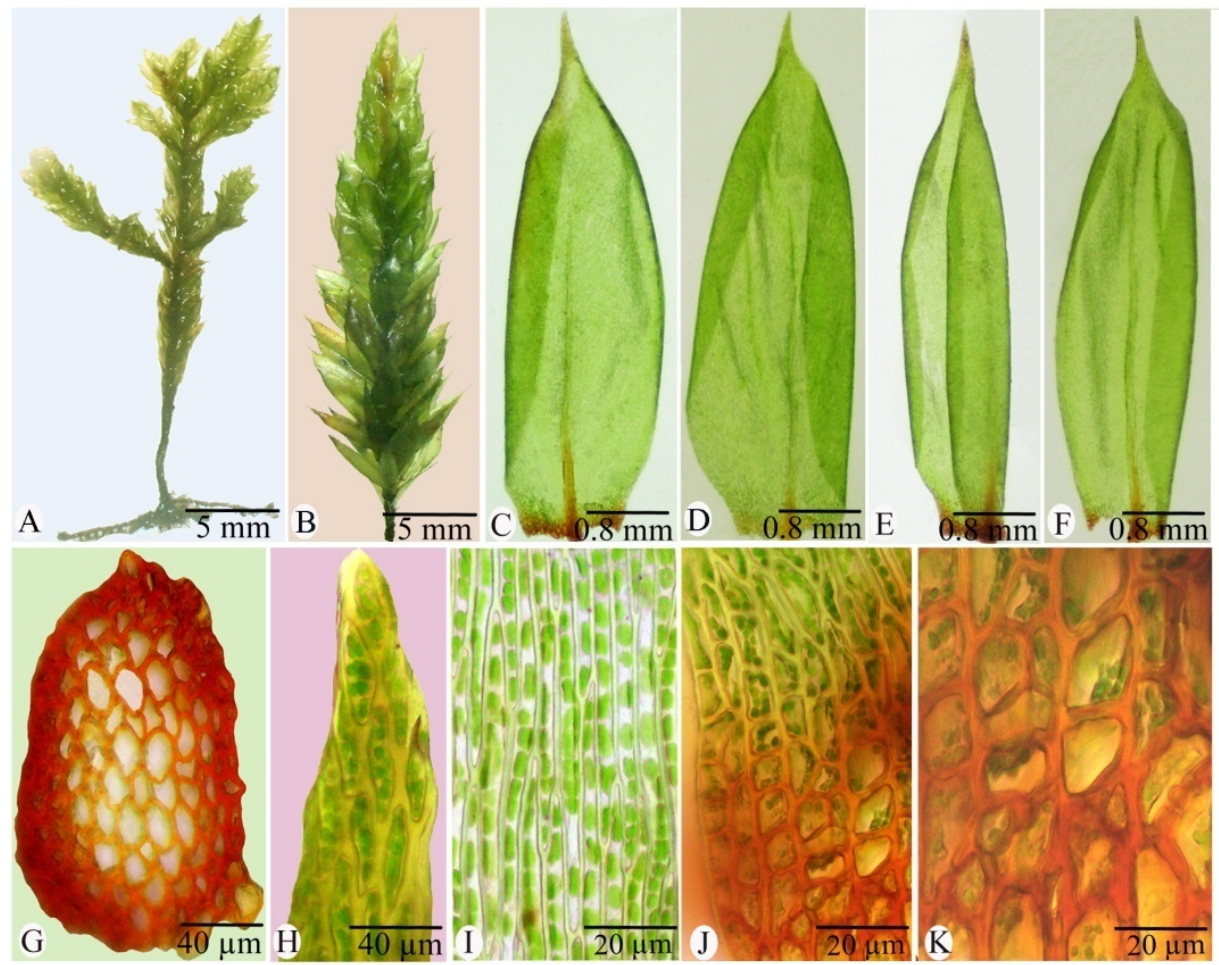

Fig. 4. Symphysodontella involuta (Thwaites \& Mitt.) M. Fleisch.

A. Plant B. Branch C\&D. Stem leaves E\&F. Branch leaves G. Cross section of stem

H. Leaf apical cells I. Leaf median cells J. Leaf basal cells K. Alar cells (P. M. Biju 2080)

5. Dixon HN. Mosses collected in Assam. J. Bombay Nat. Hist. Soc. 1937; 39: 769-795.

6. Manju CN, Rajesh KP. Symphysodontella madhusoodananii (Pterobryaceae, Moss): a new species from the Western Ghats of India. Photokeys 2012; 18: 39-44. https://doi.org/10.3897/phytokeys.18.3314

7. Kumar GV, Krishnamurthy KV. Moss flora of Shervaroy Hills of Eastern Ghats (South India). In: Nath V, Asthana AK, Editors. Current Trends in Bryology. Dehra Dun: Bishen Singh Mahendra Pal Singh; 2007. p. 227-243.

8. Sathish SS, Thamizharasi T, Palani R, Vijayakanth P, Vimala A. Checklist of mosses (Bryopsida) of the Kalrayan Hills in the Eastern Ghats of Tamil Nadu, India. Eng. Biosci. 2014; 2: 28-33.
9. Biju PM, Daniels AED. Two species of Isopterygium Mitt. - New to the Eastern Ghats in Peninsular India. Pl. Sci. Today 2016; 3: 129-134. https://doi.org/10.14719/pst.2016.3.2.223

10. Biju PM, Daniels AED. Liverworts new to the Eastern Ghats from Kolli Hills. Cryptog. Biodivers. Assess. 2016; 1: 76-82.

11. Biju PM, Daniels AED. Leucobryum aduncum var. scalare (Leucobryaceae: Bryophyta) - new to the Eastern Ghats. Pl. Sci. Today 2017; 4: 64-67. https://doi.org/10.14719/pst.2017.4.2.295

12. Palani R, Sathish SS, Thamizharasi T, Vijayakanth P. Checklist of Mosses (Bryophyta) of Bodamalai Hills in Eastern Ghats, Tamil Nadu. Pl. Sci. Today 2017; 4: 49-54. https://doi.org/10.14719/pst.2017.4.1.278 